\title{
The Complications of Donor Assisted Reproduction Anonymity
}

\author{
Jonada Zyberaj, Phd candidate \\ Lecturer at the University "Ismail Qemali" VIore, Albania
}

Ergysa Ikonomi, Phd candidate

Lecturer at the University "Ismail Qemali" Vlore, Albania

\section{Doi:10.5901/ajis.2013.v2n9p578}

\section{Abstract}

Assisted reproduction methods are becoming ever-present for couples who can't conceive a baby in a natural reproduction way. More than 5 million babies have been born worldwide since the first IVF baby was born in 1978. As medical techniques are developing in this area legislation is still trying to legitimate issues related to artificial reproduction techniques. Art in many countries relies on the principle of anonymity of donors, but with the increasing prevalence of these techniques the use of this principle led to the emergence of some legal issues as the higher interest of the child to know its origin and its genes and the legal complications in term of marriage capacity. This paper aims to treat the relationship between the right to remain an anonymous donor versus the benefits of the disclosure of the donor identity. In the discussion on the anonymity of donors vs the disclosure of their identity a crucial topic is the procedure that should be implemented to manage the personal data of the donors in order to guarantee donor's rights and place him in a comfortable position away from harassments.

Keywords: artificial reproductive technology, anonymity, disclosure, marriage capacity, higher interest of the child.

\section{Introduction}

ART has a long tradition based on anonymity. The practice of anonymity was institutionalized by the first organized nationwide programme of gamete donation, the French'Centre pour l'Etude et la Conservation des Oeufs et du Sperme' founded in 1973 (Shenfield and Steele, 1997). In Europe, donors remained anonymous until the 1980s. However, there has subsequently been a movement away from anonymity.

The issue of donor anonymity is a clue issue because of its implications with fundamental principles as privacy, personal identity, minor rights and family rights. The anonymity of the donor means to protect donor rights and his privacy. Art 8 of the ECHR define privacy as the right to respect private and family life, home and his correspondence. In exercising the privacy right there shall be no interference by a public authority except cases when it is in accordance with the law and is necessary in a democratic society.

The application of artificial reproduction methods has raised a comprehensive discussion between the right of the donor to remain anonymous and the right of the child to be informed as to respect the highest interest of the child. The balances of these rights seems to be difficult as long as legislations should provide a system that respect the right of the child to be informed and his highest interest as well as the privacy rights of the donor.

Arguments for secrecy in ART state that anonymity and secrecy are necessary to protect the birth parents, the family unit, the donor, and the donor offspring. So the interest of three units shall be respected. In the conflict between these interests the paper aims to analyze which of the two rights will be prevalent, taking into account the complications that brings the implementation of one or another principle.

\section{Disclosure of the Donor Identity vs Anonymity}

\subsection{Implications of the two principles with human rights}

Secrecy and anonymity of the donor have ruled the ART for decades but recently the need to ensure the best interest of the child has brought to attention the need of knowing the identity of the donor for social or medical reasons. 
The knowledge of genetic origins contains two parts: the first is the secrecy issue which touches the question whether the person is informed that he was conceived by means of donor material. The second part is the donor anonymity that concerns the release of the identity of the donor to the offspring (Haimes E, 1988). There has been a real evolution in terms of disclosure of the information in some European states as Switzerland, Germany, UK, Sweden which has moved forward with the disclosure of the information by giving to the offspring the right to know the identity of the donor in a certain age. The discussion on disclosure versus anonymity involve specific rights guaranteed by international conventions such as Article 7 of the United Nations Convention on the Rights of the Child which gives the child the right to know his parents as far as possible and Article 8 of the European Convention for the Protection of Human Rights and Fundamental Freedoms.

Art 8 of the European Convention for the Protection of Human Rights and fundamental Freedoms guarantee the respect of everyone private life, family, home and correspondence from any interference by public authorities. Private life, in the Court's view, includes a person's physical and psychological integrity and can sometimes embrace aspects of an individual's physical and social identity (Niemietz v. GermanY).

Anonymity as the provision of the privacy right are based on the individual right of everyone to have full control over their bodies (Lisa Shield). The donor anonymity is based on one of the fundamental freedoms such as the dignity of the human body as well as the right to have a quiet family life.

Interpreted in this way Art 8 of the ECHR protects the right of the donor to maintain the anonymity in connection with all the actions he performs with his body such as the sperm donation. On the other hand if we take in consideration that most of the donors are young students which take part in the sperm donation for financial purposes, the disclosure of their identity 18 or more years later can lead to a breach of their family life and privacy. Many authors believe that the implementation of the disclosure principle can jeopardize the entire procedure of artificial reproduction.

On the flip side is the right of the offspring to be informed on his genetic background and the protection of the highest interest of the child, guaranteed not only by the United Nations Convention on the Children Rights but even by the European Convention on Human Rights. The Court reiterates that birth, and in particular the circumstances in which a child is born, forms part of a child's, and subsequently the adult's, private life guaranteed by Article 8 of the Convention (Odièvre v. France). Respect for private life requires that everyone should be able to establish details of their identity as individual human beings and that an individual's entitlement to such information is of importance because of its formative implications for his or her personality (Mikulić v. Croatia). This includes obtaining information necessary to discover the truth concerning important aspects of one's personal identity, such as the identity of one's parents (Jäggi v. Switzerland) .

However the Council of Europe has stated that, "It is not possible at the present moment to draw decisive arguments from the Convention for the Protection of Human Rights and Fundamental Freedoms either in favor or against the anonymity of donors". ( Frith, 2007)

At the same time in the Gaskin case the Court explicitly avoided expressing an 'opinion on whether general rights of access to personal data and information may be derived from Article 8 of the Convention. (ECHR 1989) The most crucial point emphasized by the Court was that a balance should be struck between the interests of the individual seeking access to his records on the one hand and the interests of those who had supplied information in confidence, and more generally, the interests and expectations of the other people involved, on the other hand.

On the other hand, The United Nations Convention on the Rights of The Child (UNCRC) in Art. 8 commits States Parties, "to respect the right of the child to preserve his or her identity," and to provide "assistance and protection" when a child is deprived of "some or all of the elements of his or her identity". ( Sartori D.H, 2007) Article 8 requires to the domestic law to provide the offspring with information relevant to his/her genetic identity by opening previously sealed records. Also, Articles 9 and 16 facilitate meetings between donor offspring

and genetic relatives. (Shanner L. 2003) As it is seen Art 7 of the UNCRC is not inconsistent with Art 8 of the ECHR because according to the European Court of Human Rights interpretation the right of the offspring to be informed is guaranteed within the meaning of Art 8.

In the relationship between the right of the donor to remain anonymous and the right of the offspring to know the donor identity the European Court of Human Rights has left to the member states and the national legislations the obligation to protect and balance both of the rights. Member states should provide the necessary tools to protect the right of the privacy of the donor and the right of the offspring to know the donor identity.

\subsection{Implication of the anonymity principle with family law:}

Another implication in applying the anonymity principle is the impact that this principle would have in the family law and more specifically in the possibility to have a valid marriage. The validity of a marriage depends on the capacity of both 
spouses to marry. Parties will have the legal capacity to marry if they meet the following request:

$>$ Not to be in within the prohibited deegres of relationship.

$>$ Reach the age of majority

$>$ Not to be married (in a valid marriage).

$>$ Spouses of different sex (depends on the national legislation).

The prohibiteed deegres are of two kind; consanguinity (related by blood) and affinity (related by marriage or by law). Almost in all legislations (England, Germany, Belgium, France ...) there is an absolute ban on the blood relationships (consanguinity) between the two spouses. (Marriage Act 1949; Prohibited Degrees of Relationship Act 1986 of the UK German Civil Code, Belgium Family Law, France Family Law) Although legislations have gone through liberalization of marriage bans, closed blood relationships are still considered not only as a ban to the capacity to marry but also as a criminal offence. In the cases of adopted children, marriage ban weigh not only on the adopted child and his adoptive family but also on the adoptee and his family of origin. In the same light blood ties between the offspring and the sperm donor or his nearest successors would also constitute a ban for a valid marriage. Implementation of the principle of donor anonymity could lead to marital bans between the spouses to the extent to make a marriage invalid. In UK individuals who wish to have an intimate relationship, marry or enter into a civil union may check the data information on the national register to see if they are genetically related due to gamete donation. (M. Richards, G. Pennings and John B 2012)

\section{Anonymity in the EU Member States and the Albanian Case}

Prohibiting gamete donor anonymity is a growing global trend, currently adopted by some EU members and jurisdictions as Sweden, Austria, Switzerland, Netherlands, Norway, Germany, Finland and the United Kingdom have prohibited anonymous gamete donors. (Blyth \& Frith) Sweden was the first jurisdiction since 1985 to implement the non anonymity principle allowing a child born through ART procedure to disclose the identity of the donor when he reached maturity. A number of jurisdictions that promote donor anonymity have, nevertheless, established statutory donor conception registers, containing details of donors, recipients of donated gametes or embryos and children born as a result of donor procedures, and permit varying degrees of access to information held on the register ( Bielawska-Batorowicz, E .2004) The Czech Republic and Iceland operate a different scheme which is a hybrid system conventionally known as the 'double track' where a donor may choose at the point of donation either to be identifiable to any offspring or to remain anonymous. Prospective recipients of donated gametes may then choose to receive the gametes of either an anonymous or identifiable donor. Thus, both donors and recipients may exercise choice, at the time of donation and receipt respectively, although the future options available to any donor-conceived person are restricted by the choice made by their parents. (Blood, J., Pitt, P., Baker, G. and Foster, P. 2001) A particularly recent development has been the 'Voluntary Contact Register', which full title is the 'Donor Treatment Procedure Information Register,' but is colloquially known as the 'Voluntary Register,' thus providing the generic description of such registers. (Blyth, E. 2004) The idea behind such registers is that where donation has been made anonymously, information can be disclosed with the mutual consent of the parties involved (offspring at a certain age and the donor).

In every legislation of the states that has implemented the disclosure principle, regardless of how it is applied, the right of the offspring to know the identity of the donor depends entirely on whether his parents would tell him that he is born under an ART procedure. Despite of the methods that would be implemented in order to respect the right of the offspring to know the donor identity, the privacy rights of the donor should be respected. Legislations should ensure the discrete maintenance of the donor's data under an effective system because in the end is not the right but its boundaries that need to be shown. (Albin Eser)

From 2002 Albania jurisdiction legitimates the artificial reproduction techniques with the "Reproductive Health" Law. Art 2 of this law giving the meaning of the "reproductive health" defines it as "....people's ability to reproduce and the freedom to decide the manner and timing of reproduction...." (Art 2 of the Albanian "Reproductive Health" Law), gives to each individual (not only to marital couples) the opportunity to choose the methods of reproduction. The "Reproductive Health" law legitimates the application of different techniques of artificial reproduction by couples who are infertile or when the donor is not the mother's partner. (Art.10 of the Albanian "Reproductive Health Law) The procedures of artificial reproduction which are related to heterologous reproduction are only mentioned but not specifically defined in law, but the law itself provides for the possibility of implementation of this regulation in other normative acts. Until now no regulations on this field are implemented. Even in Albania the techniques of ART are followed by the principle of anonymity. Art 14 of the "Reproductive Health" law, imposes an obligation on medical services to preserve the confidentiality and the 
anonymity of the data. The donor anonymity is not explicitly guaranteed by law but in the interpretation of this provision it imposes the obligation of keeping anonymous data included here (by interpretation) even the identity of the donor.

Artificial reproduction methods are applied relatively late in Albania compared to other European countries and there has been no cases of offspring asking for the identity of the donor even if it is expected that this is going to happen very soon and therefore the Albanian legislation should be such to guarantee the right of the offspring to know his identity and the right for privacy of the donor. Human rights arguments have been advanced in support of disclosure of donor identity in many EU countries which are strictly using donor anonymity and I think that even the Albanian legislation shall follow this trend. Albania is a signatory of the United Nations Convention on The Right of the Child and of the European Convention of Human Rights of which derive the obligations to respect and protect the best interest of the child, his right to preserve his or her identity and the privacy of the donor. The Constitution of the Republic of Albania protects the right of privacy. According to the Constitution the treatment of personal data by other persons can be made with the approval of the person to whose the personal data belong (in this group are also included even health or sexual data). (Art 35 of the Constitution of the Albanian Republic)

Cases where prior consent is not required are defined only by law. In the decision of the Constitutional Court of Albania, the court stated that "...personal data of a sensitive nature deserve a different treatment from that involving property...". (Decision of the Albanian Constitutional Court, No.16 date 11.11.2004)

From the constitutional point of view it is possible to implement the disclosure principle for the donor but it is necessary to implement this principle under a strictly procedure for the administration of donor's data.

Another implication of the donor anonymity principle is that with family law mentioned even in the second part of this paper. Even the Albanian Family Law provides marital bans one of which are also the closed degrees of consanguinity and affinity relationships between the two spouses. According to the Albania Family Law blood ties constitute a ban for a valid marriage. (Art 10 of the Albanian Family Law 2004) This does not only concludes blood ties between biological family members but also between tha adoptee and his adoptive family and the adoptee and his biological family. The existed application of the anonymity principle can lead to invalid marriages between people with blood relationships because of their lack of knowing. (Art 40 of the Albanian family Law 2004)

\section{Recomandations}

Since 2002 Albania has an incomplete legislation on the artificial reproduction. The techniques of artificial reproduction and the basic principles of its functioning are implemented in the "Reproductive Health" Law and it seems that apparently they have not merited an extended treatment. Ministry of Health does not have accurate official data on the number of babies born each year by the application of ART, even though more often it hears about more and more couples who undergo such techniques and where many of them are foreigners who choose the Albanian "market" due to its low cost. The lack of information related not only to the babies born by the implementation of these techniques, but even to donors, is the proof of a weak administration and a lack of management in this area which can lead to misuse of the information.

In front of this lack of management is difficult to conclude on what should be improved because the legislation over this topic in Albania is incomplete. This is why in a possible development of the legislation in this field I would rather recommend:

> Setting up a data base register, administered by the Ministry of Health on which all identity and health situation data of all parties (recipient, donor and offspring) shall be recorded.

$>$ Granting the right of the offspring to be informed in a certain age about his genetic origin.

$>$ Remove the principle of donor anonymity and replace it with the disclosure principle, granting so the right of the offspring to know the donor identity, as an obligation arising from ECHR and UNCRC.

$>$ Implementation of such a system to balance the right of the child to be informed about its genetic background and the highest interest of the child and the right of privacy of donors.

This paper has so demonstrate the legal complexity associated with the principle of the donor anonymity and the right of the offspring to know. It is hoped that through highlighting this discrepancies and the legal limits this research will aid further consideration and progress on the ART legislation in Albania and will strengthen the protection of the offspring rights.

\section{References}

Albanian Constitutional Court http://www.gjk.gov.al/

Albanian Family Law 2004. 
Albin Eser (1985) "The Human Genetics in the light of German Law", pg 565, Freiburg University

Aurela Anastasi "Constitutional Law" 2010 pg 149

Belgium Family Law

Bielawska-Batorowicz, E. (2004) Poland: provision and guidelines for third party assisted conception. In E. Blyth and R. Landau (eds) Third Party Assisted Conception Across Cultures: Social, Legal and Ethical Perspectives. London: Jessica Kingsley Publishers.

Blood, J., Pitt, P., Baker, G. and Foster, P. (2001) Parents' decision to inform children of their donor (sperm) conception and the impact of a register which legislates to enable identification of donors. Paper presented at the 17th World Congress on Fertility and Sterility, Melbourne.

Blyth \& Frith, Mary Lyndon Shanley, Collaboration and Commodification in Assisted Procreation: Reflections on an Open Market and Anonymous Donation in Human Sperm and Eggs, 36 LAW \& SOC. REV. 257, 266-70 (2002) pg 174-76.

Blyth, E. (2004) Human Fertility 7, 3,pg 157-162.

Constitution of the Albanian Republic

Council of Europe http://hub.coe.int/

European Court of Human Rights Official Website http://www.echr.coe.int/Pages/home

France Family Law

Frith C and Frith U (2007), Social cognition in humans. Curr Biol 17, R724- R 732.

Gaskin v. the United Kingdom, 7 July 1989, §§ 36-37, 39, Series A no. 160)

German Civil Law

Haimes E 'Secrecy': What Can Artificial Reproduction Learn from Adoption? 1988 Int J Law Family 2: 46-61. PMID: 12449953 [PubMed indexed for MEDLINE]

Health Law Review "Consistency and privacy: Do these legal principles mandate gamete donor anonymity" Lisa Shield.

Jäggi v. Switzerland, no. 58757/00, § 25, ECHR 2006.

Lisa Shield "Consistency and privacy: Do these legal principles mandate gamete donor anonymity" pg 46, Health Law Review Vol 12 , Nr.1

Marriage Act 1949 (c. 76)" and Marriage (Prohibited Degrees of Relationship) Act 1986

Mikulić v. Croatia, no. 53176/99, §§ 53-54, ECHR 2002-I

Niemietz v. Germany, judgment of 16 December 1992, Series A no. 251-B, pp. 33-34, § 29

Odièvre v. France [GC], no. 42326/98, § 29, ECHR 2003-III

Reproductive Donation, Practice, Policy and Bioethics Martin Richards, Guido Pennings and John B. Appleby (Jul 30, 2012).

"Reproductive Health" law Nr 8876 date 04.04.2002

Sartori D.H. 2007. H. Cmara de Diputados de la Nacin. Proyecto de Resolucion. Archive 0808-D-2007. Trmite Parlamentario 013 (19/03/2007). Pedido de Informes al Poder Ejecutivo sobre los Controles de las Instituciones de Medicina Reproductiva y Bancos de Semen, en Relacio Verhey LFM Het recht op inzage in persoonsdossiers 1990 NJCM Bulletin 15: 206-217.

Shanner 2003 Shanner L. 2003. Derecho a la identidad en donacin de gametes. Aspectos legalesy psicolgicos. Viewpoint Legal Challenges to Donor Anonymity. Reproduccion Humana. Volume 11, Number 3 pg. 25-27

Shenfield and Steele (1997)., What are the effects of anonymity and secrecy on the welfare of the child in gamete donation? Human Reproduction vol.12 no.2 pp.392-395, 1997; http://humrep.oxfordjournals.org/content/12/2/392.full.pdf

Xytex Corporation, Profile of "Featured Donor," http://www.xytex.com/featured/page=essay (last visited May 15, 2013) (on file with author). 